\title{
細胞外ベシクルの構造特性と機能制御
}

JST 戦略創造研究推進事業（ERATO）バイオナノトランスポータープロジェクト*1)・京都大学 工学研究科*2)

下田麻子*1,2) ・澤田晋一*1,2) ・秋吉一成*1,2)

\section{Characterization and Functional Modification of Extracellular Vesicles}

Cells from various origins release vesicles with unique biophysical and biochemical properties, making them of interest for diagnostic and therapeutic purposes. These extracellular vesicles are classified based on their biogenesis and size: vesicles formed by exocytosis of multivesicular bodies are called exosomes (with diameters from 30 to $200 \mathrm{~nm}$ ), vesicles budded directly from the plasma membrane are called microvesicles (with diameters from 100 to $1000 \mathrm{~nm}$ ) and vesicles derived from apoptotic cells are apoptotic bodies (with diameters from $1 \mu \mathrm{m}$ to $5 \mu \mathrm{m}$ ). Extracellular vesicles play an important role in intercellular communication (they transfer proteins and/or miRNA between cells), therefore, they could be used as useful biomarkers of various diseases and drug delivery vehicles. In this review, we highlight fundamental information of extracellular vesicles including vesicle classification, standard protocols for isolation and characterization.

新たな細胞間コミュニケーションツールとして、細胞外ベシクルが注目されている。ベシクル の種類は、その発生機序、サイズにより大きく分けて 3 つに分類できる ( エクソソーム : 30〜

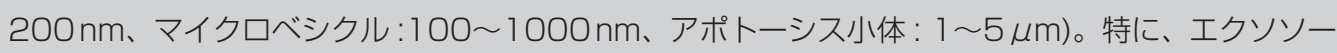
ムに関してはその内部にタンパク質や micro RNA を含有していることから、疾患治療や予後診断、 バイオマーカーとしての応用が期待される。本稿では、細胞外ベシクルの基礎的概念、単離方法や機 能評価法などを紹介する。

$$
\text { Asako Shimoda }{ }^{* 1,2)} \text {, Shin-ichi Sawada*1,2), Kazunari Akiyosht*1,2) }
$$

Keywords: Extracellular vesicles, Exosome, Microvesicle, Isolation, Characterization

\section{1. はじめに}

あらゆる細胞は、脂質二重膜に囲まれたナノ〜マ イクロサイズのベシクルを細胞外へと分泌すること が知られている。当初は細胞内の老廃物を細胞外に 輸送するシステムとして考えられていたが、その内 部にタンパク質のみならず、生体内で遺伝子発現抑 制に重要な働きを示す micro RNA を保持している ことが発見されたため、細胞間のコミュニケーショ ンッールとして近年、注目を浴びている。また、細 胞のみならず血液や体液、尿、母乳などの体液にも 存在することから、治療、予後診断、バイオマー

${ }^{* 1)}$ Exploratory Research for Advanced Technology, Japan Science and Technology Agency, Bio-nanotransporter Project

${ }^{* 2}$ Department of Polymer Chemistry, Graduate School of Engineering, Kyoto University
カーとさまざまな分野への応用が期待される このベシクルの大きさは $30 \mathrm{~nm}$ から $1 \mu \mathrm{m}$ と幅広 く、細胞起源や生物学的機能などにより、数種類に 分類される。本特集で取りあげるエクソソームも

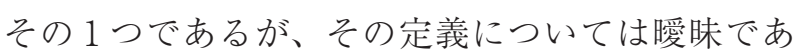
る。International Society for Extracellular Vesicle (ISEV) (http://www.isevmeeting.org/)では、こ れら細胞外分泌顆粒の総称として、Extracellular Vesicle $(\mathrm{EV})$ と呼ぶことを提唱している。本章では、 細胞外ベシクルの特徵やその単離方法、機能化によ る応用について解説する。

\section{2. 細胞外ベシクルの種類と構成因子}

細胞外ベシクルは、粒子サイズ、構成成分、形 
成メカニズムに基づき種々の名前で呼ばれてい る。ここでは、生成機構による、(1)エクソソーム、 (2)マイクロベシクル、(3)アポトーシス小体の 3 つに ついて概説する。

\section{1) エクソソーム (Exosome)}

エンドサイトーシスにより形成したエンドソーム は、まず初期エンドソームを形成し、続いて後期エ ンドソームへと移行する。この後期エンドソーム がさらに内側にくびれて形成する腔内膜小胞 (ILV, intraluminal membrane vesicle) を多数含む多胞性 エンドソーム (MVB, multivesicular body)が細胞膜 と融合すると、ILVは細胞外へ放出される。このよ うな機構で分泌される直径が 30〜200nm の小胞が エクソソームと呼ばれている。

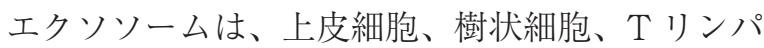
球、幹細胞など、さまざまな細胞および血液、尿な どの体液からも分泌される。構成因子としてタンパ ク質、mRNA や miRNA が挙げられるが、特にシャ ペロン分子である Hsc70, Hsc90 やテトラスパニン (CD9, CD63，CD81) が特異的に存在していると報 告されている ${ }^{7 \sim 10)}$ 。

エクソソームを構成する分子に関するデータベー ス ExoCarta (www.exocarta.org) が存在し、また、 細胞外ベシクル全般の最新の情報を知ることができ る。

\section{2)マイクロベシクル (Microvesicle)}

エクソソームとマイクロベシクルの違いは明確に はされていないが、一般にサイズや構成分子、分 泌機構により区別される。マイクロベシクルは細 胞膜の一部がくびり取られ、ダイレクトに分泌さ れる直径 100 1000 nm の粒子である。Shedding microvesicle や ectosome とも呼ばれている。い くつかの報告では、マイクロベシクルに特異的 なマーカーとして、flotillin-2, selectin, integrin, metalloproteinase などのタンパク質や、脂質にお いては、特にホスファチジルセリンが高発現してい るとされている。発生メカニズムは、アゴニストの 添加、刺激、障害などさまざまである。細胞膜を構 成するリン脂質は、通常、ホスファチジルセリン
(PS) は細胞膜の内側に、ホスファチジルコリン (PC) は外側に配置している。この局在は Flippase およ び aminophospholipid translocase の 2 つの酵素に より、ATP 依存的に保たれている。しかし、細胞 内カルシウム濃度が高くなるとこの機能が低下し、 代わりに脂質を双方向に輸送する働きを持つスクラ ンブラーゼという酵素活性が増加する。これに加え て、細胞内システインプロテアーゼであるカルパイ ンもカルシウム濃度依存的に活性化される。その結 果、アクチンが切断され、細胞骨格の再編成を経て 膜小胞の形成となる ${ }^{11 \sim 12)}$ 。

\section{3)アポトーシス小体 (Apoptotic blebs)}

アポトーシス小体は、約 1〜 $5 \mu \mathrm{m}$ で、すべての 細胞種によりアポトーシスの遅い段階に形成され る。エクソソームやマイクロベシクルが通常の細胞 過程で起こるのに対し、アポトーシス小体は、プロ グラムされた細胞死が起こったときのみ生じる。こ の際、細胞膜ホスファチジルセリンの表面への露出 や細胞の凝縮、断片化が起こる。その後、膜の水疮 形成および核の凝集・断片化が進むとアポトーシス 小体が形成される。一般に、細胞はアポトーシス小 体に急速に断片化され、すぐにマクロファージに嶺 食される。アポトーシス小体の遺伝物質の情報伝 達についてもいくつか報告があり、腫瘍移植マウ スの血管内でアポトーシス小体が検出された例や、 EGFP 発現ヒト臍帯静脈内皮細胞 (HUVEC) から単 離したアポトーシス小体を新生児ラットの心筋細胞 に移植すると EGFP の蛍光が確認された例が挙げ られる。これらの知見はアポトーシス小体が遺伝物 質の伝達を担っていることを示唆しているが、サイ ズ分布が広いことから、単離の方法が未確立である などさらなる検討が必要である ${ }^{13 \sim 15)}$ 。(図 1,2＆表1)

\section{3. 単離方法および特性評価法}

\section{3-1) 単離方法}

細胞外ベシクルの単離方法は、(1)超遠心法、(2)精 密濾過法、(3)抗体による捕捉、(4)マイクロ流体シス テムの利用、(5)その他が挙げられる。 


\section{(1)超遠心法}

超遠心による単離は最も多く用いられている手法 である。まずは 300～2,000 g の低速度で細胞成分や $\sim 1 \mu \mathrm{m}$ 程度のアポトーシス小体の除去を行い、次 に $10,000 \sim 20,000 \mathrm{~g}$ もしは $0.22 \mu \mathrm{m}$ のフィルター
処理でマイクロベシクルを除去する。これらの段階 的遠心処理後に $100,000 \mathrm{~g} \sim 120,000 \mathrm{~g}$ の超遠心を行 うことでエクソソーム画分が回収できる。得られた 沈殿にはエクソソームと同程度の大きさのタンパク 質も夾雑物として含まれているので、エクソソー

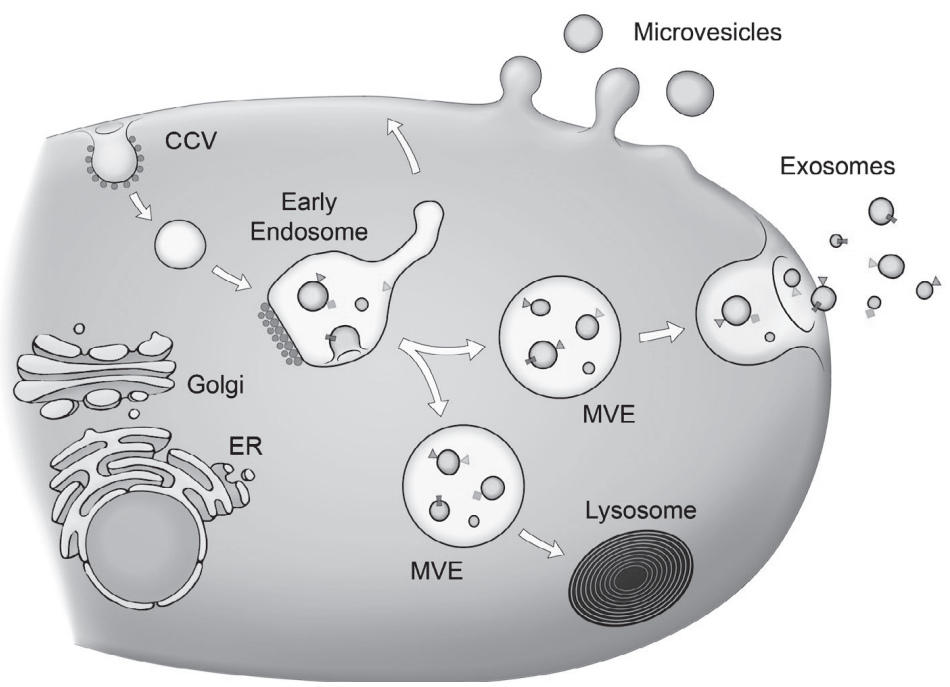

図 1 細胞外ベシクルの分泌経路(Raposo G et al. ${ }^{9}$ を引用)
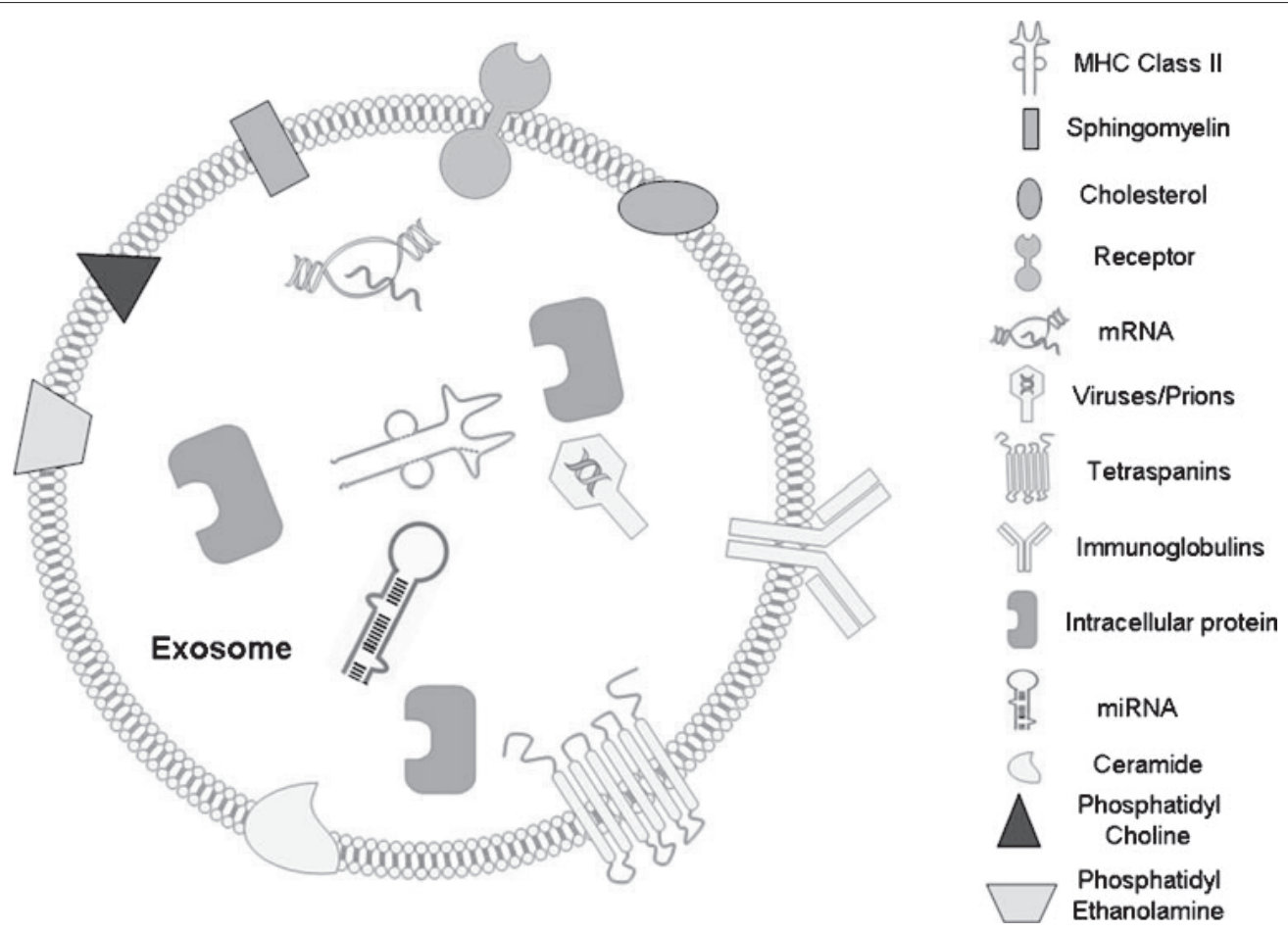

図 2 エクンソーム中の構成タンパク質

CD9, CD63, CD81 などのテトラスパニン、Heat shock protein などが主にエクソソームマーカーとして知られている。(Azmi AS et al. ${ }^{10}$ を引用) 
表 1 細胞外ベシクルの特徴

\begin{tabular}{|c|c|c|c|}
\hline ベシクルの種類 & エクソソーム & マイクロベシクル & アポトーシス小体 \\
\hline サイズ(nm) & $30 \sim 200$ & $100 \sim 1000$ & $0.50 \sim 5000$ \\
\hline 密度 $(\mathrm{g} / \mathrm{mL})$ & $1.10 \sim 1.21$ & Undetermined & $1.16 \sim 1.28$ \\
\hline 沈殿の際の遠心速度(g) & $100,000 \sim 200,000$ & $10,000 \sim 20,000$ & $1,200,10,000$ or 100,000 \\
\hline 脂質組成 & $\begin{array}{c}\text { コレステロール、 } \\
\text { スフィンゴミエリン、セラミド }\end{array}$ & $\begin{array}{l}\text { コレステロール、 } \\
\text { ホスファチジルセリン }\end{array}$ & ホスファチジルセリン \\
\hline 主なマーカータンパク質 & CD63, CD9, CD81,Alix, Tsg101 & Selectins, Integrins, CD40 & Histones, DNA \\
\hline 放出のメカニズム & $\begin{array}{l}\text { 多胞性エンドソームのエキソサイ } \\
\text { トーシスによる放出 }\end{array}$ & 細胞膜からの出芽 & $\begin{array}{l}\text { 細胞の凝縮、断片化の後に形成 } \\
\text { される小胞体の出芽 }\end{array}$ \\
\hline 内包物 & $\begin{array}{l}\text { mRNA, microRNA (miRNA), non- } \\
\text { coding RNAs; 細胞質及び膜タンパク } \\
\text { 質、MHC (major histocompatibility } \\
\text { complex) 分子 }\end{array}$ & $\begin{array}{l}\text { mRNA, miRNA, non-coding } \\
\text { RNAs; 細胞質及び膜タンパク質 }\end{array}$ & 核断片、細胞小器官 \\
\hline
\end{tabular}

ムの密度が $1.10 \sim 1.21 \mathrm{~g} / \mathrm{mL}$ であることを利用し、 ショ糖密度勾配遠心を組み合わせることで精製でき る。大量培養が必要なことや、超遠心に時間を要す るなどの欠点があるが、確実にエクソソーム画分を 得られる簡便な方法と言える。

\section{(2)精密濾過法}

$0.1 \sim 0.8 \mu \mathrm{m}$ の段階的フィルター処理にて、死細 胞、アポトーシス小体、マイクロベシクルを除去す る手法であり、通常は超遠心法と組み合わせて用い ることが多い。尿からのエクソソーム分離において この手法が用いられているが、メンブレンへのタン パク質吸着による収量の減少や、ベシクルの形状変 化、サイズの大きいベシクルや血小板の破砕による コンタミネーションなどの問題があるのが現状であ る。

\section{(3)抗体による捕捉}

細胞外ベシクルに特有の表面タンパク質、特に CD9, CD63, CD81 などのテトラスパニンの抗体を コートした磁気ビーズにより細胞外ベシクルを捕捉 する方法である。ほかにも、腫瘍関連マーカーであ る HER2 や EpCAM 抗体を用いた例が報告されて おり、この手法により得られたべシクルは特異性が 高く、フローサイトメトリーやイムノブロット、免 疫電顕などによる機能評価が容易であるという利点 が挙げられる。最近では、この原理を用いた八ウ スキーピングタンパク質である Rab-5 およびCD63 を用いたサンドイッチELISA による血漿由来エク
ソソームの単離 kit(ExoTEST ${ }^{\mathrm{TM}}$, HANSABIOMED, Tallinn, Estonia)が市販されている。しかし、すべ てのベシクルに特定のマーカーが存在しているわけ ではないため、（1）の超遠心法に比べさらに収量は 少なくなる。

\section{(4)マイクロ流体システムの利用}

微細加工技術を用いて微小な分析装置を基板に形 成することで溶液の反応、分離、検出などの操作を ミクロ化するマイクロ流体システムの開発が盛ん に行われている。この技術を応用し、Chen らは抗 CD63抗体を固定化したデバイスを作製し、数百 $\mu \mathrm{L}$ の血清サンプルからベシクルの単離、回収、さら にはRNAの抽出までを短時間で行っている ${ }^{19)} 。 ま$ た、Shao らはデバイスに固定化したベシクルをマ イクロオーダーの核磁気共鳴システム $(\mu \mathrm{NMR}) に$ より検出した ${ }^{20)}$ 。検出感度が高いことから、腫瘍細 胞と正常細胞のベシクルの分離が可能であり、予測 診断ツールとしての応用が期待される。しかし、一 度に解析できるサンプル量に限りがあるため、(3) の抗体による捕捉と同様に収量が少なく、また得 られたベシクルの純度に関する課題も残っている。 Ichiki らは抗体のかわりにPEG(ポリエチレングリ コール)脂質誘導体を修飾したデバイスによるエク ソソーム精製法を開発している。抗体による捕捉方 法は、その抗体に特異的なエクソソームしか回収さ れないのに対し、この方法ではエクソソームを構成 する脂質二重膜との相互作用を利用するため、吸着 量が高いといった利点がある。捕捉されるべシクル 
のサイズも制御可能となることから、超遠心法に代 わる新たな細胞外ベシクル精製法としての応用が期 待される

\section{(5)その他}

(1)の超遠心法や(2)の精密濾過法の後に、サイズ排 除クロマトグラフィーを用いて精製する方法も報告 されている。超遠心法よりもさらに時間を要するが、 発現量が比較的少ないタンパク質についても検出可 能な利点がある22)。

ベシクル回収の時間短縮や超遠心を必要としない ベシクル単離技術の確立を目的とし、いくつかのバ イオ企業により単離キットが開発されている。代表 的なものとして、ExoQuick ${ }^{\mathrm{TM}}$ (System Biosciences, Mountain View, CA, USA)、Total Exosome Isolation kit(Invitrogen, Carlsbad, CA, USA), PureExo ${ }^{\circledR}$ Exosome Isolation kit (101Bio, Palo Alto, CA, USA)が挙げられる。どの手法も付属の試薬と 培養上清または体液を混合して静置し、低速度によ る遠心分離でベシクル(これらはエクソソームのみ を単離すると記載している)を回収するというもの である。超遠心に比べて、サンプル量が少なくて済 み、短時間でサンプルを得られることから、これら を用いて単離したエクソソームの機能評価を報告し ている論文がいくつか報告されている。初めて扱う 細胞からエクソソームが分泌されているかどうかを 調べるには最も簡便な方法であるが、リポプロテイ ンなどの混入による純度の問題やエクソソームに発 現しているタンパク質や miRNA を超遠心法により 回収したサンプルと比較して異なるデータが得られ たという報告もあることから、こちらも他の手法と 組み合わせて用いるなどの工夫が必要かもしれな w。

以上 5 つの異なる細胞外ベシクルの単離方法を挙 げたが、すべてにおいて長所・短所が挙げられるた め、現時点では超遠心法による単離をべースとし、 目的に合わせて手法を選択し行うのがよいと考えら れる。

\section{3-2)特性評価法}

(1)ウエスタンブロット

細胞外ベシクルに発現しているタンパク質を調べ るのに適した方法である。テトラスパニンやヒート ショックプロテイン、アクチンなど、さまざまな種 類のタンパク質に対する抗体が市販されているの で、エクソソームを単離した際にタンパク質の発現 量を確認するのに優れた手法といえる。超遠心法お よび密度勾配遠心法で得られたベシクルはほとんど 精製されたエクソソームといえるが、市販のキット を用いて回収したべシクルには不純物が含まれてい る可能性があるので、両者を比較してみるとよい。

\section{(2)電子顕微鏡}

ベシクルの形状を観察するのに、透過型電子顕微 鏡 (Transmission Electron Microscopy; TEM)は最 も簡便な方法である。四酸化オスミニウムや酢酸ウ ラニル、リンタングステン酸などの重金属で染色す ることで、ベシクルの脂質二重膜が観察できる。ま た、ベシクルに特有のマーカータンパク質を金ナノ 粒子で標識することも可能である。ただし、測定時 は脱水、固定、真空下で行うためベシクルが収縮し、 多少の形状変化が起こる。一方で、クライオ TEM (cryo-TEM) は、試料を急速凍結させ固定化するこ とで、上記の影響を受けずに形状を保持したまま観 察できる。この手法を用いることにより、今までに “cup-shaped”とされていたエクソソームの形状は球 状に近い“mushroom-shaped”であることが確認さ れている。

\section{(3)ナノ粒子解析装置 (Nano Tracking Analysis; NTA)}

ナノ粒子のブラウン運動の様子をリアルタイムで 観察し、粒子の分散・凝集を個々に解析する装置 (LM Series, Nanosight, Amesbury, UK) である。ス トークス・アインシュタインの式より粒子の移動速 度からサイズを算出することができる。分解能が高 く細かい分布が得られるのが特徵である。 


\section{(4)ナノパーティクル計測器 (qNano)}

圧力可変モジュール (VPM) を使用し、ナノポア に粒子と溶液を同時に通過させることにより、個別 に粒子を計測する装置である(IZON Science Ltd)。 NTA が一定量の粒子の個数を要するのに対し、低 濃度および少ないサンプル量でも測定ができる。

\section{(5)フローサイトメトリー}

細胞や微粒子のレーザー光を照射した際に得られ る散乱光または蛍光を利用して、粒子特性を評価す る手法であり、細胞外ベシクル表面のタンパク質の 発現量や細胞内への取り込みを評価するのに適して いる。ただし、検出限界が $300 \mathrm{~nm}$ 前後であるため、 一般にエクソソームを測定する際には、抗体を修飾 したマイクロメーターサイズのラテックスビーズや 磁気ビーズに結合させる必要がある。定量やベシク ルの種類の区別などは難しいが、細胞への取り込み 挙動を観察するには最も簡便な方法であるといえ る。エクソソームの診断応用に関しては、小坂、落 谷らの章を参照していただきたい。

\section{4. エクソソームの機能改変 (エクソソーム工学)}

生体に従来備わっている細胞間コミュニケーショ ンツールであるエクソソームに、人工的に新たな機 能を付与することで、細胞の機能制御や、低分子薬 物・核酸・タンパク質などの輸送担体としての応用 が進められている。エクソソームの機能改変手法と しては、(1)遺伝子工学的手法により分泌細胞を改変 する手法や、(2)機能性材料によるエクソソームの人 工的機能化法などが挙げられる。

\section{1)遺伝子工学的手法による機能改変}

近年、遺伝子工学的手法を用いたさまざまなエク ソソームの機能改変について報告されている ${ }^{23)}$ 。例 えば、ウイルスベクターを用いて任意のタンパク質 遺伝子を細胞に導入し、その細胞からエクソソーム を回収する方法がある。Kurodaらはがん細胞に高 発現する EGFR (epidermal growth factor receptor) を標的とするぺプチドを膜上に発現するエクソソー ムを作製したところ、効率よく細胞へ取り込まれた ことを報告している ${ }^{24)}$ 。また、Alvarez-Ervitiらは

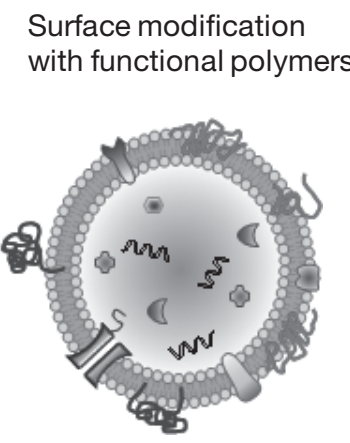

Nanogel/exosome hybrid

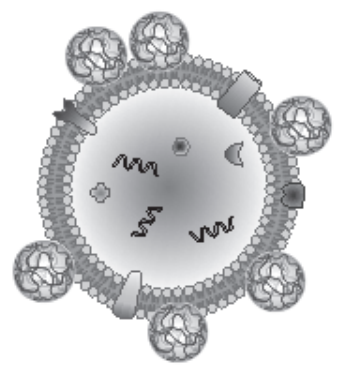

Exosomes-trapping Gel

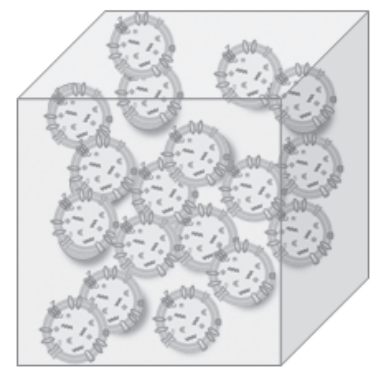

Liposome/exosome hybrid
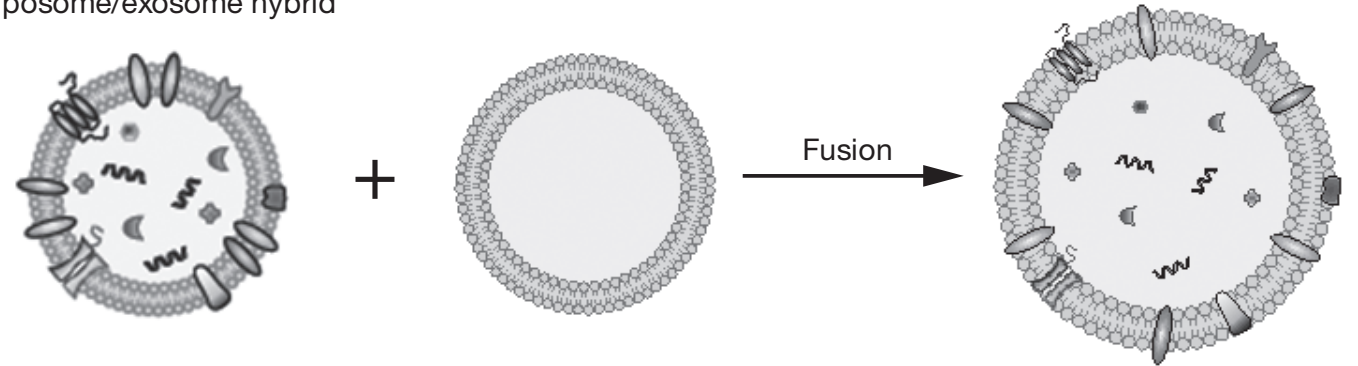

図 3 エクソソームの機能化 
siRNAのデリバリーキャリアとしてエクソソーム を用いている。狂犬病ウイルス糖タンパク質 $(R V G$; 神経細胞に発現するアセチルコリン受容体と特異的 に結合)およびエクソソームマーカーの 1 つである LAMP $2 \mathrm{~b}$ を発現させたエクソソームを作製し、エ レクトロポレーションにて siRNAを封入したもの をマウスに静注したところ、中枢神経での RNAi 誘 導に成功している ${ }^{25)}$ 。この結果はエクソソーム自体 を治療の目的に応じて改変することが可能であり、 薬剤のキャリアとしても使用できることを示唆して いる。エクソソームの細胞内取り达み機構や体内動 態については、高橋、西川、高倉らの章で詳細に述 ベられている。 SiRNAのエクソソームへの導入法 としては、エレクトロポレーションが最も有効であ るとされているが、再現性にそしいことや、最近で はエレクトロポレーションにより SiRNA が凝集す るといった報告もされている ${ }^{26)}$ 。特定の miRNA を 細胞に過剩発現させ、その miRNA を多く含有する エクソソームを得る方法も報告されている ${ }^{27)}$ 。エク ソソームの DDS 応用についての詳細は、黒田の章 を参考にしていただきたい。

\section{2) エクソソームの人工的機能化}

人工的に設計、合成された機能性材料を用いた工 クソソームへの新たな機能付与手法も開発されつつ ある。我々は、エクソソーム機能改変による人工工 クソソームの構築や機能性高分子、ナノゲル、リポ ソームなどとの複合化によるハイブリッドエクソ ソームの開発を行っている。例えば、エクソソーム 単体では細胞内への取り込みや組織移行性は十分で はないことから、疎水化多糖ナノゲル材料との複合 化により、エクソソームの細胞内導入効率の向上や 徐放性制御を検討している(図 3)。これまでに、親 水性の多糖に疎水性基を部分的に置換した疎水化多 糖が、希薄溶液中で約 $30 \mathrm{~nm}$ のナノゲルを形成し、 タンパク質(癌ワクチン、経鼻ワクチン)や核酸(遺 伝子、siRNA)のキャリアとして優れていることを
報告した ${ }^{28 \sim 29)}$ 。また、この自己組織化ナノゲルは、 エクソソームと同様な構造を有するリポソームの表 面を被覆しえることを報告しており、実際、エクソ ソームの表面も効率よく疎水化多糖ナノゲルにより 被覆、修飾しえることを見いだした。カチオン性ナ ノゲル ${ }^{30)}$ を用いるとエクソソームの細胞内導入効率 が大きく向上した。細胞親和性ナノゲル ${ }^{31}$ を用いる ことで、組織指向性も制御しえる可能性がある。さ らに、我々はナノゲルボトムアップ法により、ナノ ゲルを集積した新規マクロゲル材料を開発し、ナノ ゲル/リポソームハイブリッドゲルによるリポソー ムの徐放にも成功しており ${ }^{32)}$ 、再生医療応用のため のエクソソームを封入した新規ゲル材料の開発を進 めている。

我々は、一方で、エクソソームと種々のリポソー ムが複合化や条件によっては融合することを見いだ しており、エクソソームの新規な機能化法としてそ の有用性を検討している(図 3)。

\section{5. おわりに}

エクソソーム発見当初は、単に不要な細胞内物 質を放出するための機構と考えられてきたが、近 年、エクソソーム中には数百種類のタンパク質、 mRNA、miRNA やDNA が内部に存在しており、 細胞間の遺伝情報の伝達に大きな役割を果たしてい ることが報告された。その存在や作用は多様であり、 母子間での情報伝達からエクソソームの分泌量依存 によるがんの進行具合の指標など生体内のあらゆる 場所で重要なファクターとなっていることは間違い ない。

ここ数年で細胞外ベシクルに関する論文は数多く 発表されているが、未だ簡便かつ再現性のよい単離 方法の確立や細胞への導入効率の改善などさまざま な課題も残っている。今後、これらの問題を解決す ることで、画期的な疾患の診断・治療法の確立へと つながると期待される。 


\section{文献}

1) Simons M, Raposo G. Exosomes-vesicular carriers for intercellular communication. Curr Opin Cell Biol. 21, 575-581 (2009)

2) Théry C., Ostrowski, M. \& Segura, E. Membrane vesicles as conveyors of immune responses. Nat Rev Immunol. 9, 581-593 (2009)

3) Chaput N., Théry C. Exosomes: immune properties and potential clinical implementations. Semin Immunopathol. 33 419-459 (2011)

4) EL Andaloussi S, Mäger I, Breakefield XO, Wood MJ. Extracellular vesicles: biology and emerging therapeutic opportunities. Nat Rev Drug Discov. 12, 347-357 (2013)

5) Borges FT, Reis LA, Schor N. Extracellular vesicles: structure, function, and potential clinical uses in renal diseases. Braz J Med Biol Res. 46, $824-830$ (2013)

6) Akers JC, Gonda D, Kim R, Carter BS, Chen CC. Biogenesis of extracellular vesicles (EV): exosomes, microvesicles, retrovirus-like vesicles, and apoptotic bodies. J Neurooncol. 113, 1-11 (2013)

7) Simpson RJ, Lim JW, Moritz RL, Mathivanan S. Exosomes: proteomic insights and diagnostic potential. Expert Rev Proteomics. 6, 267-283 (2009)

8) Vlassov AV, Magdaleno S, Setterquist R, Conrad R. Exosomes: Current knowledge of their composition, biological functions, and diagnostic and therapeutic potentials. Biochim Biophys Acta. 1820, 940-948 (2012)

9) Raposo G, Stoorvogel W. Extracellular vesicles: exosomes, microvesicles, and friends. J Cell Biol. 200, 373-383 (2013)

10) Azmi AS, Bao B, Sarkar FH. Exosomes in cancer development, metastasis, and drug resistance: a comprehensive review. Cancer Metastasis Rev. 32, 623-642 (2013)

11) Cocucci E, Racchetti G, Meldolesi J. Shedding microvesicles: artefacts no more. Trends Cell Biol. 19, 43-51 (2009)

12) Roseblade A, Luk F, Rawling T, Ung A, Grau GE, Bebawy M. Cell-derived microparticles: new targets in the therapeutic management of disease. J Pharm Pharm Sci. 16, 238-253 (2013)

13) Bergsmedh A, Szeles A, Henriksson M, Bratt A, Folkman MJ, Spetz AL, Holmgren L. Horizontal transfer of oncogenes by uptake of apoptotic bodies. Proc Natl Acad Sci U S A. 98, 6407-6411 (2001)

14) Burghoff S, Ding Z, Gödecke S, Assmann A, Wirrwar A, Buchholz D, Sergeeva O, Leurs C, Hanenberg H, Müller HW, Bloch W, Schrader J. Horizontal gene transfer from human endothelial cells to rat cardiomyocytes after intracoronary transplantation. Cardiovasc Res. 77, 534-543 (2008)

15) Meckes DG Jr, Raab-Traub N. Microvesicles and viral infection. J Virol. 85, 12844-12854 (2011)

16) Théry C, Amigorena S, Raposo G, Clayton A. Isolation and characterization of exosomes from cell culture supernatants and biological fluids. Curr Protoc Cell Biol. Chapter 3: Unit 3.22. (2006)

17) El-Andaloussi S, Lee $Y$, Lakhal-Littleton S, Li J, Seow Y, Gardiner C, Alvarez-Erviti L, Sargent IL, Wood MJ. Exosome-mediated delivery of siRNA in vitro and in vivo. Nat Protoc. 7, 2112-2126 (2012)
18) Witwer KW, Buzás EI, Bemis LT, Bora A, Lässer C, Lötvall J, Nolte-'t Hoen EN, Piper MG, Sivaraman S, Skog J, Théry C, Wauben MH, Hochberg F. Standardization of sample collection, isolation and analysis methods in extracellular vesicle research. J Extracell Vesicles. May 27; 2. (2013)

19) Chen, C., Skog, J., Hsu, C., Lessard, R. T., Balaj, L., Wurdinger, T., Carter, B. S., Breakefield, X. O., Toner, M., Irimia, D. Microfluidic isolation and transcriptome analysis of serum microvesicles. Lab Chip. 10, 505-511(2010)

20) Shao, H., Min, C., Issadore, D., Liong, M., Yoon, T., Weissleder, R., Lee, H. Magnetic nanoparticles and microNMR for diagnostic applications. Theranostics. 2, 55-65(2012)

21）一木隆範、「体液エクソソームの診断プラットフォーム」、細 胞工学, 32(1), pp. 91-95 (2013)

22) Rood IM, Deegens JK, Merchant ML, Tamboer WP, Wilkey DW, Wetzels JF, Klein JB, Comparison of three methods for isolation of urinary microvesicles to identify biomarkers of nephrotic syndrome. Kidney Int. 78, 810-816 (2010)

23) Marcus ME, Leonard JN, FedExosomes: Engineering Therapeutic Biological Nanoparticles that Truly Deliver. Pharmaceuticals (Basel).6, 659-680 (2013)

24) Ohno S, Takanashi M, Sudo K, Ueda S, Ishikawa A, Matsuyama N, Fujita K, Mizutani T, Ohgi T, Ochiya T, Gotoh N, Kuroda M. Systemically injected exosomes targeted to EGFR deliver antitumor microRNA to breast cancer cells. Mol Ther. 21, 185-191 (2013)

25) Alvarez-Erviti, L, Seow, Y, Yin, H, Betts, C, Lakhal, S and Wood, MJ, Delivery of siRNA to the mouse brain by systemic injection of targeted exosomes. Nat Biotechnol. 29, 341-345 (2011)

26) Kooijmans SA, Stremersch S, Braeckmans K, de Smedt SC, Hendrix A, Wood MJ, Schiffelers RM, Raemdonck K, Vader $\mathrm{P}$, Electroporation-induced siRNA precipitation obscures the efficiency of siRNA loading into extracellular vesicles. J Control Release. 172, 229-238 (2013)

27) Munoz JL, Bliss SA, Greco SJ, Ramkissoon SH, Ligon KL, Rameshwar P, Delivery of Functional Anti-miR-9 by Mesenchymal Stem Cell-derived Exosomes to Glioblastoma Multiforme Cells Conferred Chemosensitivity. Mol Ther Nucleic Acids. 2, el26 (2013)

28) Sasaki Y., Akiyoshi K, Nanogel engineering for new nanobiomaterials: from chaperoning engineering to biomedical applications. The Chemical Record. 10, 366-376 (2010)

29) Sasaki Y., Akiyoshi K, Self-assembled Nanogel Engineering for Advanced Biomedical Technology. Chem. Lett. 41, 202208 (2012)

30) Ayame H, Morimoto N, Akiyoshi K, Self-assembled cationic nanogels for intracellular protein delivery system. Bioconjugate Chem. 19, 882-890 (2008)

31) Shimoda A, Sawada S, Akiyoshi K, Cell Specific PeptideConjugated Polysaccharide Nanogels for Protein Delivery. Macromol Biosci. 11, 882-888 (2011)

32) Sekine Y, Moritani Y, Ikeda-Fukazawa T, Sasaki Y, Akiyoshi $\mathrm{K}$, Hybrid hydrogel biomaterial by nanogel engineering: bottom-up design with nanogel and liposome building blocks to develop a multi-drug delivery system, Advance Healthcare Materials, 1, 722-728 (2012) 